\title{
Apolipoprotein A5 Measurement
}

National Cancer Institute

\section{Source}

National Cancer Institute. Apolipoprotein A5 Measurement. NCI Thesaurus. Code C103355.

The determination of the amount of the apolipoprotein A5 in a sample. 